\title{
Inflation: Assessing Its Recent Behavior and Future Prospects
}

\author{
R. W. HAFER
}

T

HE inflation rate in the United States has gone through a remarkable decline during the past three years. In the first quarter of 1980 , the inflation rate, measured by movements in the GNP deflator, stood at 10.01 percent. In the first quarter of 1983 , it was down to 5.64 percent. This dramatic change has been attributed to a variety of things. Monetary policy typically is one reason given for the drop in inflation. Improving productivity and lower wage demands also have received some credit. Declines in oil prices precipitated by concessions among OPEC oil producers is mentioned as well. ${ }^{1}$

In general, popular discussion of the inflation problem suggests that inflation finally has been tamed. ${ }^{2}$ As one analyst noted recently, "It now looks as if we can have our cake and eat it too - get a solid economic recovery, while inflation continues to decline." 3 The purpose of this paper is twofold. First, it provides evidence about the relative importance of monetary

\footnotetext{
'See, for example, Bluford Putnam, "This Money Bulge Isn't Inflationary," Wall Street Journal, April 27, 1983; Peter Grier, "Why Continued Success is Likely in Effort to Tame Inllation." Christian Science Monitor, February 28, 1983; Harry B. Ellis, " Drop in Oil Prices, Interest Rates, and Inflation Could Mean Stronger Recovery," Christian Science Monitor, February 28, 1983, and Jonathan Fuerbringer, "Consumer Prices Up Slight $0.2 \%$," New York Times, February 26, 1983.

${ }^{2}$ See "Brokerage Says Inflation May be Under Control for Years," Christian Science Monitor, May 19, 1983; and Linda Stern, "Econonists Optimistic on Inflation Outlook," New York Journal of Commerce, February 28, 1983. For another viewpoint, see Alfred L. Malabre, Jr., "Though Consensus Sees Mild Inflation Ahead, Some Signs Suggest a Returning Price Spiral, "Wall Street Journal, May 3, 1983. Caroline Atkinson, "Inflation Still Alive and Influencing Policy," Washington Post, February 24, 1983; and "Index Forewarns Inflation Resumption," New York Journal of Commerce, May 18, 1983

${ }^{3}$ David Jones, chief economist of Aubrey Lanston \& Co., quoted in Grier, "Why Continued Success is Likely in Effort to Tame Inflation."
}

and nonmonetary factors in explaining the behavior of inflation during the past few years. Specifically, it assesses the impact of energy price developments in conjunction with monetary growth changes on the measured inflation rate. Second, it provides some simulation results for inflation through 1985 . If the future resembles the past - that is, if the empirical relationship between money growth and inflation remains intact - recent celebrations of the permanent demise of inflation are premature.

\section{THE MONEY GPONTH-INE'LATON LINT}

Economists define inflation as a persistent rise in the general level of prices for goods and services. Inflation is primarily a monetary phenomenon; that is, the primary factors influencing future inflation are the current and past behavior of the money stock. This view is based on empirical evidence amassed over a variety of periods and across diverse economies. As one example, Friedman and Schwartz conclude, after examining the link between money growth and inflation in the United States and the United Kingdom from 1867 to 1975 , that "except only for the United States interwar period, the ultimate effect of monetary change is absorbed by prices." 4

While this monetarist approach to explaining inflation focuses attention primarily on the growth of the money supply, it does not ignore the effect of nonmonetary factors in the short run. While nonmonetary

\footnotetext{
${ }^{4}$ Milton Friedman and Anna J. Schwartz, Monetary Trends in the United States and the United Kingdom: Their Relation to Income, Prices, and Interest Rates, 1867-1975 (University of Chicago Press, 1982), p. 627 .
} 
forces, such as wage and price controls, wage increases above productivity changes or OPEC oil price changes do not have a lasting influence on the rate of inflation, they can produce temporary effects on the measured inflation rate. Consequently, inflation often deviates temporarily from the rate determined solely by the growth of money.

To see how this can occur, consider the price behavior shown in figure 1 . The line labeled $\ln P$ represents how the log of the price level would behave, over time, if monetary pressures alone affected prices, and if the trend rate of money growth were constant. Because the price level is shown in terms of its logarithm, the change over time (that is, $\ln \mathrm{P}_{t}-\ln \mathrm{P}_{t-1}$ ) represents the growth rate of the price level - the inflation rate.

Suppose at time $t_{0}$ an increase in the price of oil occurs, as it did in late 1973 and again in 1979. One effect of the oil price increase is to reduce the aggregate supply of goods through the economic obsolescence of some existing capital equipment. ${ }^{5}$ If aggregate demand remains unchanged, the result is an increase in the level of prices (the jump from $\ln P$ to $\ln \mathrm{P}^{*}$ ) over and above what would result from trend money growth alone. The period of adjustment to the new, higher price level $\left(\ln \mathrm{P}^{*}\right)$ is depicted in figure 1 by the time span $t_{0}$ to $t_{1}$. During this period the rate of change of prices - that is, the slope of the line $\ln P^{*}$ relative to the line $\ln \mathrm{P}$ - is greater than that explained by money growth alone. This represents the fact that, from $t_{0}$ to $t_{1}$, the measured rate of inflation is higher than that attributed solely to monetary factors, represented by the line $\ln P$. Once the adjustment period ends, however, the rate of inflation returns to the monetary rate, represented by the common slope of the lines $\ln \mathrm{P}^{*}$ and InP. Thus, while nonmonetary factors can influence the measured inflation rate for relatively brief periods, monetary factors determine the long-term path of inflation. ${ }^{6}$

${ }^{5}$ A discussion of this effect is presented in Denis $S$. Karnosky, "The Link Between Money and Prices - 1971-76," this Review (June 1976), pp. 17-23; and John A. Tatom, "Energy Prices and ShortRun Economic Performance," this Review (Jantary 1981), pp. 3-17. A broader analysis can be found in Robert $H$. Rasche and John A. Tatom, "Energy Price Shocks, Aggregate Supply and Monetary Policy: The Theory and International Evidence," Carne" gie-Rochester Conference Series, Vol. 14 (1981).

${ }^{6}$ Empirical evidence for this argument is presented in Robert J. Gordon, "Wordd Inflation and Monetary Accommodation in Eight Countries," Brookings Papers on Economic Activity (2:1977), pp. 409-68; and James R. Barth and James T. Bennett, "Cost-push versus Demand-pull Inflation: Some Empirical Evidence," Joturthal of Money, Credit and Banking (August 1975), pp. 391-97. For a general discassion, see Dallas S. Batten, "Inflation: The Cost-Push Myth," this Review (June/July 1981), pp. 20-26.
Figure 1

The Effect of Monmonetary Factors on the Measured Rafe of Inllation

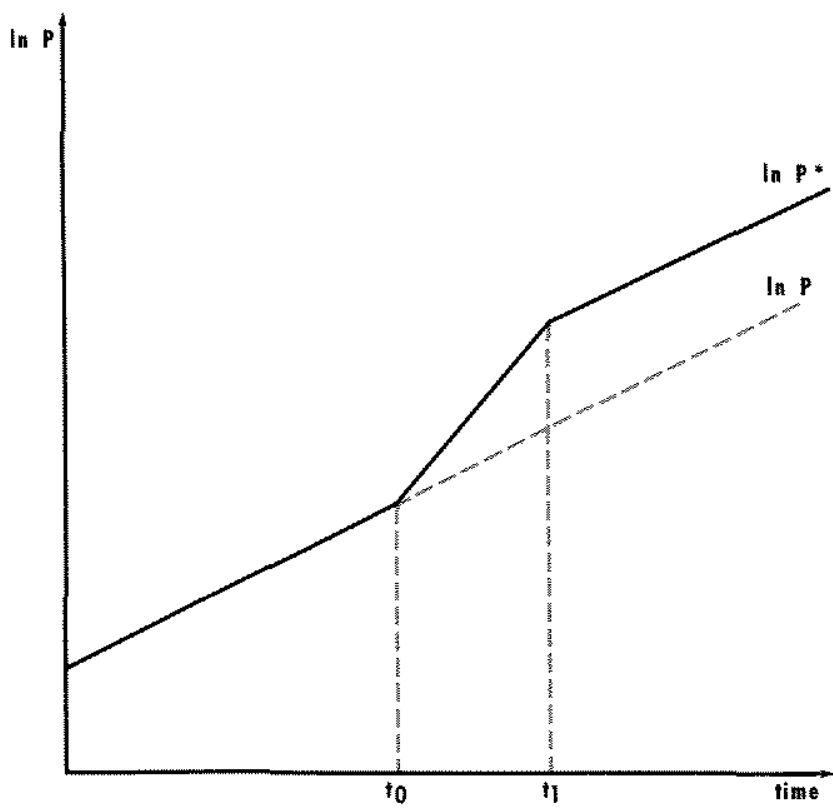

To illustrate the persistent relationship between money growth and inflation, chart 1 plots the threeyear average rate of money growth (M1) and the annual rate of inflation for the past two decades. The threeyear average of $\mathrm{Ml}$ growth is used because studies indicate that changes in money growth affect prices with a lag. ${ }^{7}$ Although the inflation rate seldom equals the long-run average rate of money growth exactly, it moves around the average money growth, as if the average growth of money sets the norm for the inflation rate. This observed tendency provides the basis for monetary policy actions intended to reduce inflation. ${ }^{8}$

Chart 1 reveals that, while inflation may wander from the rate dictated by average money growth, such departures are short-lived. These deviations reflect the previously discussed transitory influence of nonmonetary factors that impinge on the price level. For example, the measured rate of inflation was below the

\footnotetext{
'See, for example, Keith M. Carlson, "The Lag From Money to Prices," this Review (October 1980), pp. 3-10; and Albert E. Burger, "Is Inflation All Due to Money?" this Review (December $1978)$, pp. $8-12$

${ }^{8}$ See, "Announcement," Federal Reserve Bulletin (October 1979), p. 830. Specifically, "appropriate constraint on the supply of money and credit is an essential part of any program to achieve the needed reduction in inflationary momenturn and inflationary expectations."
} 
Chart I

\section{Trend Money Growth and Inflation}

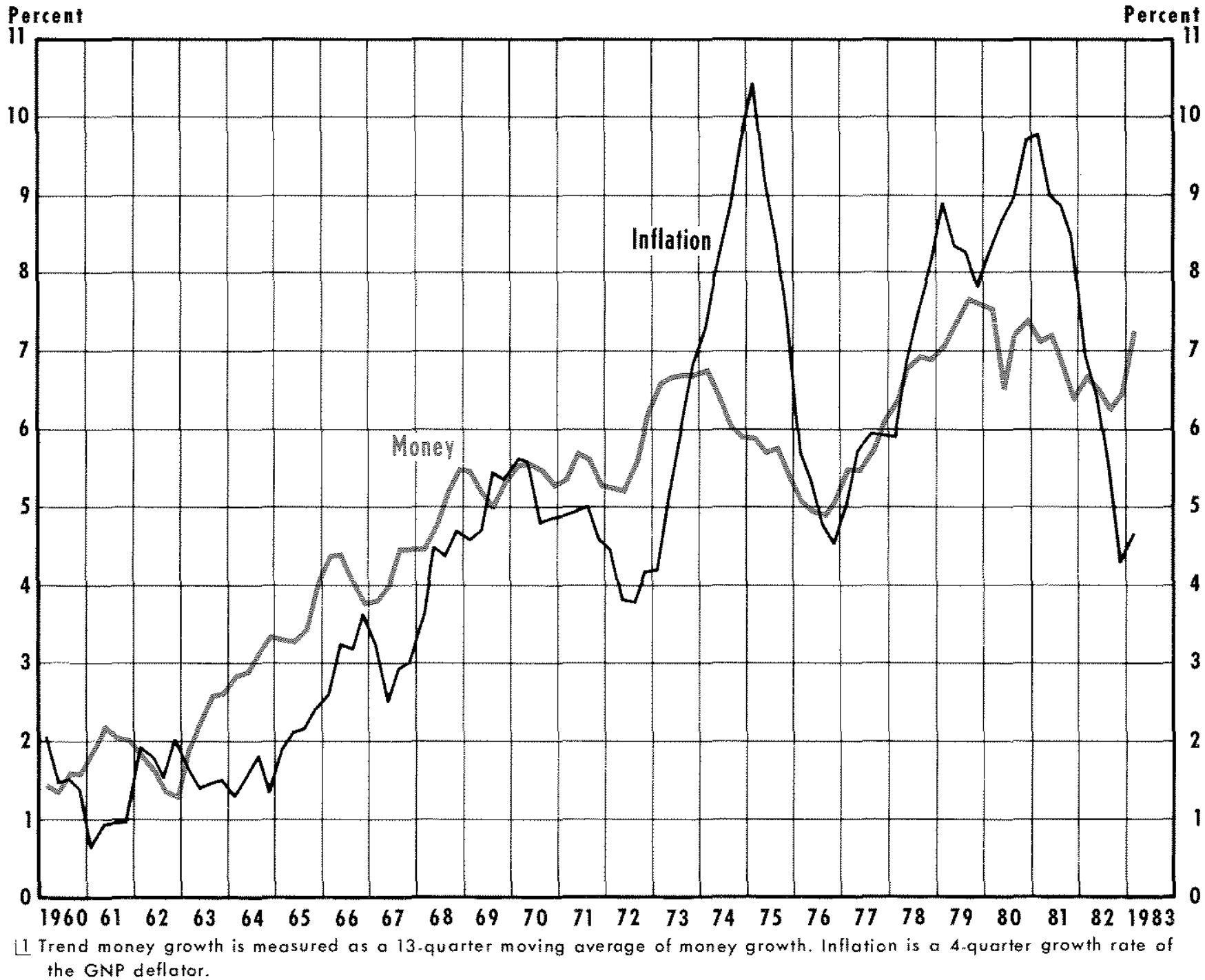

average money growth rate during the early $1970 \mathrm{~s}$, reflecting the Nixon administration's imposition of wage and price controls. The removal of these controls, along with the dramatic increase in OPEC oil prices in late 1973, account for the sharp increase in the inflation rate above average money growth. Oil price shocks again explain much of the similar behavior of inflation in the $1978-80$ period. $^{9}$

${ }^{9}$ See Karnosky, "The Link Between Money and Prices;" "Tatom, "Energy Prices and Short-Run Economic Performance;" and Rasche and Tatom, "Energy Price Shocks, Aggregate Supply and Monetary Policy."

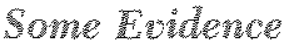

The relationship portrayed in chart 1 suggests that short-term movements in inflation can be explained by accounting for the influence of money growth and a few

For a more general discussion of relative price shocks and their effects on measured rates of inflation, see Alan S. Blinder, "The Consumer Price Index and the Measurement of Recent Inflation," Brookings Papers on Economic Activitu $(2: 1980)$, pp. 539-65; Stanley Fischer, "Relative Price Shocks, Relative Price Variability, and Inflation," Brookings Papers on Economic Activity (2:1981), pp. 381-431; and Lawrence S. Davidson, "Inflation Misinformation and Motetary Policy, "this Review (June/July 1982), pp. 15-26. 
specific nonmonetary factors that have influenced the measured rate of inflation. One relationship that has been used to successfully explain inflation uses a distributed lag of money growth to capture the "underlying" monetary infuence on inflation, and changes in the relative price of energy as one measure of short-run influences that produce deviations of inflation from its trend. ${ }^{10}$ Estimated for the sample period $\mathrm{I} / 1960$ to IV/1979, the results are (t-statistics in parentheses) ${ }^{\text {II }}$

$$
\begin{aligned}
& \text { (1) } \dot{\mathrm{P}}_{\mathrm{t}}=-0.838+1.100 \stackrel{12}{\Sigma} \dot{\mathrm{M}}_{\mathrm{t}-\mathrm{i}}+0.008 \mathrm{EP}_{\mathrm{t}-1} \\
& \begin{array}{lll}
(-2.13) & (12.36) \mathrm{i}=0 \quad(0.51)
\end{array} \\
& +0.051 \mathrm{EP}_{\mathrm{t}-2}-0.011 \mathrm{EP}_{\mathrm{t}-3}+0.052 \mathrm{EP}_{\mathrm{t}-4} \\
& (2.55) \\
& (-0.54) \\
& \overline{\mathrm{R}}^{2}=0.815 \quad \mathrm{SE}=1.164 \quad \mathrm{DW}=1.85
\end{aligned}
$$

where $\dot{\mathrm{P}}=$ rate of change of prices, measured as the first difference in the natural logarithm of the GNP deflator,

$\dot{\mathbf{M}}=$ rate of change in the money stock, measured as the first difference in the natural logarithm of M1, and

$\dot{E P}=$ rate of change in the relative price of energy. ${ }^{12}$

Summarizing the results, the $\overline{\mathrm{R}}^{2}$ indicates that the estimated relationship captures over 80 percent of the variation in inflation, with slightly over a 1 percent average prediction error $(\mathrm{SE}=1.16)$. The estimated coefficient on the money term (1.100) reveals that a 1 percentage-point increase in the long-run average growth of money will lead to an increase in inflation of about 1 percentage point. ${ }^{13}$ Changes in relative energy prices generally have a significant influence on the measured inflation rate. Consequently, omitting their

\footnotetext{
${ }^{10}$ See Tatom, "Energy Prices and Short-Run Economic Performance." The equation estimated here is slightly modified.

${ }^{11}$ The equation is estimated using a contemporaneous and 12 lagged terms of money growth. An Almon polynominal estimation procedure is employed where the degree of the polynominal is set at four. No endpoint constraints are used. The estimated equation also includes two dummy variables to capture the effects of the wage and price control imposition and removal during the early $1970 \mathrm{~s}$. Thus, the dummy variable (D) has a unity value during the control period of IIJ/1971-I/1973 and zero otherwise. The second dummy variable (D2) is used to capture the phasing out of controls, taking on a unity value for the period I/1973-I/1975 and zero elsewhere. The estimated coefficients (and their t-statistics) are: $\mathrm{D} 1=-1.83(-3.65)$ and $\mathrm{D} 2=0.72(1.24)$.

${ }^{12}$ The relative price of energy is defined as the ratio of the fuels and related products and power component of the producer price index to the business sector deflator.

${ }^{13}$ The estimated value of 1.10 is not statistically different from unity at the 5 percent level of significance $(t=1.12)$.
}

influence would give a misleading signal of the effect of a change in average money growth on the rate of inflation. ${ }^{14}$

The results presented in equation I conform to the explanation presented earlier. That is, there is a oneto-one correspondence between money growth and inflation over the long run, and nonmonetary factors may account for significant departures from that rate over shorter time periods.

\section{EXAMINING TH RECENT DROP IN INILATION}

Between the first quarter of 1980 and the first quarter of 1983, the rate of inflation has fallen over 4 percentage points. How much of this decline is due to the monetary policies of the past few years? How much is due to favorable changes in the relative price of energy?

To answer these questions, equation 1 was used to produce out-of-sample forecasts of the inflation rate from $\mathrm{I} / 1980$ to $\mathrm{I} / 1983$. Two forecasting experiments were conducted using the estimates reported in equation 1: First, one set of inflation rate forecasts was generated using the actual pattern of money growth and relative energy price changes that occurred during this period. The second set of inflation forecasts was obtained by assuming that energy prices had remained unchanged and that changes in money growth alone were responsible for the reduction in inflation. These two sets of inflation forecasts are reported in table 1. The actual rate of inflation during this period also is presented for purposes of comparison.

The quarter-to-quarter variability in the actual inflation rate is evident in table 1 . For example, the average inflation rate across the 13-quarter period was 7.35 percent with a standard deviation of 2.51 percent. The resulting coefficient of variation (standard deviation/ mean) is 0.34 percent. In contrast, the inflation rate forecasts generated using only money growth show little variation over the period: their standard deviation is only 0.36 percent and, given an average value of 6.63 percent, their coefficient of variation is only 0.05 percent. What these statistics suggest is that quarterto-quarter inflation forecasts that are based on trend money alone fail to capture much of the sizable shortrun variation in recent inflation.

\footnotetext{
${ }^{34}$ Adding the relative energy price terms significantly increases the explanatory power of the estimated equation at the 5 percent level. Using a standard F-test, the calculated F-statistic is 5.80 .
} 


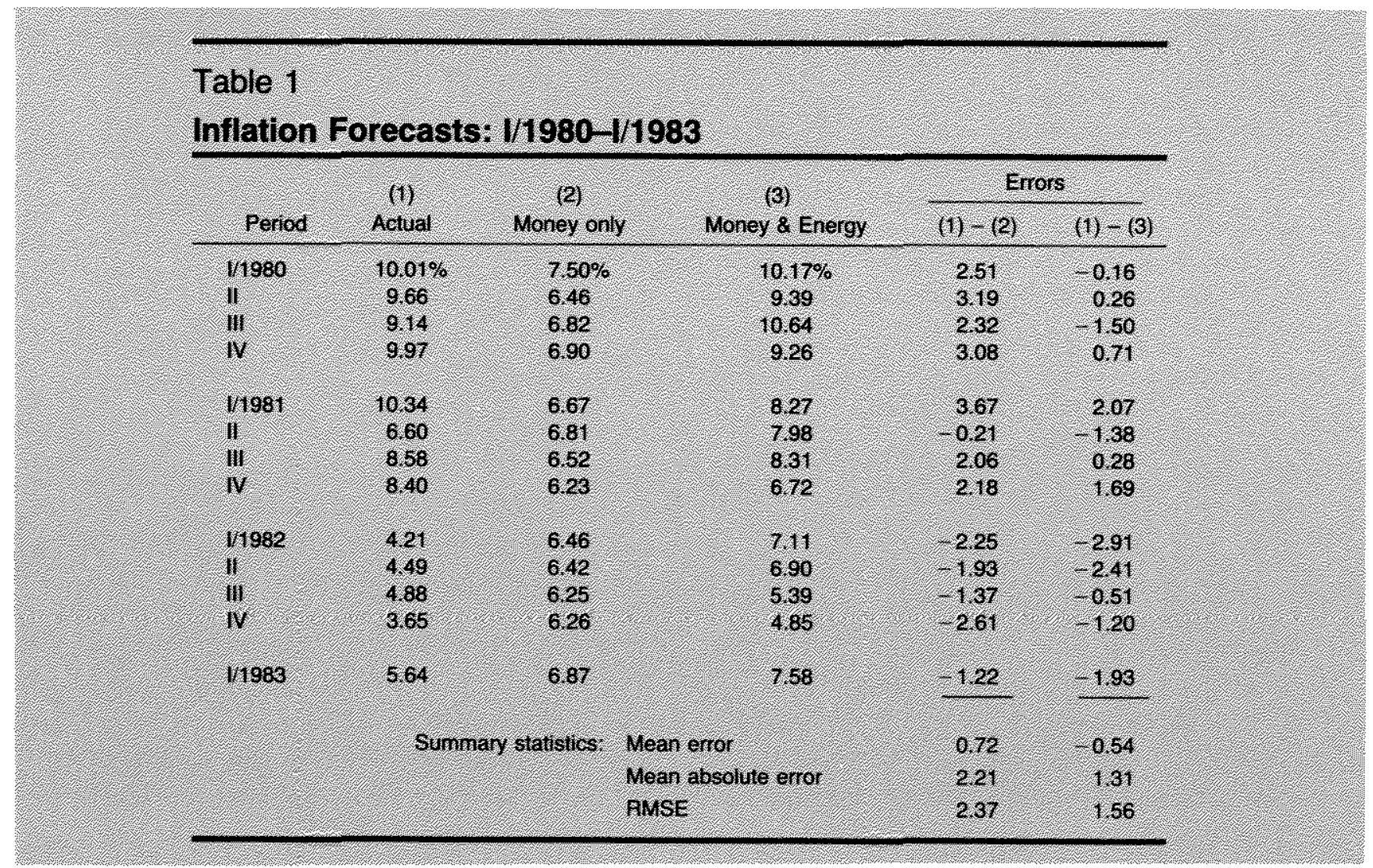

The forecast results using money and energy price effects (column 3, table 1) do better in modeling recent short-term movements in inflation. This result is made more explicit by comparing the forecast errors from the two experiments in the last two columns of table 1 . The forecast errors derived from the "money only" model display a number of large mistakes. For example, six of the errors are two or more standard deviations away from what equation 1 normally would predict. In contrast, only two such errors are found in the moneyplus-energy equation's forecast.

The summary statistics reported in table 1 provide additional evidence indicating that the forecast errors are reduced considerably when energy price changes are included along with the monetary factors. Although each model has a relatively small mean error, the mean absolute error and root-mean-squared error (RMSE) for the money-plus-energy price model is noticeably lower than that for money alone ${ }^{15}$

${ }^{15}$ The root-mean-squared error is defined as

$$
\text { RMSE }=\sqrt{\frac{\sum_{\mathrm{t}=1}^{\mathrm{N}}\left(\dot{\mathrm{P}}_{\mathrm{t}}^{\mathrm{A}}-\dot{\mathrm{P}}_{\mathrm{t}}^{\mathrm{F}}\right)^{2}}{\mathrm{~N}}}
$$

where $\dot{\mathrm{P}}^{A}$ is the actual rate of inflation, $\dot{\mathrm{P}}^{\mathrm{E}}$ is the forecasted rate,
The forecast results suggest that energy price developments have contributed significantly to the recent decline in inflation. The overall conclusion derived from these empirical results is that, while the downward path of money growth during the past few years accounts for the basic downward trend of inflation, declining energy prices are the primary reason why the actual rate of inflation in 1982 was less than the rate determined by money growth alone. ${ }^{16}$

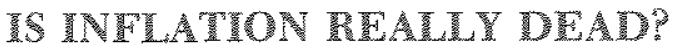

The average rate of money growth can be viewed as a measure of the underlying rate of inflation. Although recent energy price reductions have caused measured inflation to fall below average money growth, past

and $N$ is the number of periods being forecast. The RMSE for the full model is well within two standard errors of the equation, in contrast with that from the forecasts based only on money growth.

${ }^{16}$ This is not to say, however, that money growth played a minor role in forecasting recent inflation. To see this, we omitted money growth and ased only energy price changes to forecast inflation. The result is a dramatic failure to accurately predict inflation: the mean forecast error across the $1 / 1980-1 / 1983$ period using only changes in the relative energy price is -6.93 percent, and the RMSE is 7.09 percent. These statistics are dramatically larger than those reported in table 1 for either model. 
Table 2

Intation Simulation Results. 1988-85

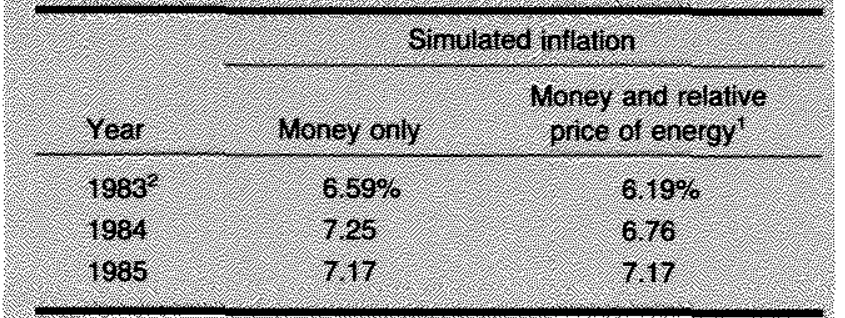

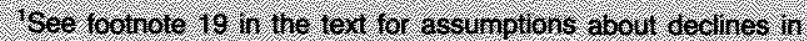

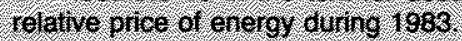

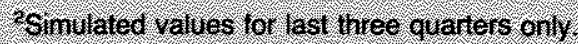

experience suggests that once these nonmonetary influences have dissipated, inflation will tend toward the average growth of money. Thus, if there were no further relative price shocks in the near future and if money growth were to remain at its present trend rate, what would the underlying inflation rate be over the next few years?

Simulated inflation rates for the $1983-85$ period given the above scenario are presented in the first column of table $2 .{ }^{17}$ These suggest that, if the average rate of money growth remains at 7.5 percent, its trend rate in $\mathrm{I} / 1983$, future inflation rates likely will be higher than the current rate. For instance, the simulated

\footnotetext{
${ }^{17}$ The simulations were calculated by re-estimating equation 1 for the period $1 / 1960-1 / 1983$. The results are (t-statistics in parentheses):

$$
\begin{aligned}
& \text { (1) } \dot{\mathrm{P}}_{\mathrm{t}}=-0.702+1.065 \stackrel{12}{\Sigma} \dot{\mathrm{M}}_{\mathrm{t}-\mathrm{i}}+0.003 \mathrm{EP}_{\mathrm{t}-1}
\end{aligned}
$$

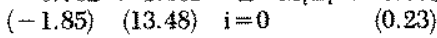

$$
\begin{aligned}
& +0.055 \mathrm{EP}_{\mathrm{t}-2}+0.001 \mathrm{EP}_{t-3}+0.038 \mathrm{EP}_{\mathrm{t}-4} \\
& \begin{array}{lll}
(3.59) & (0.09) & (2.79)
\end{array} \\
& -1.716 \mathrm{D} 1+0.762 \mathrm{D} 2
\end{aligned}
$$

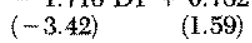

$$
\begin{aligned}
& \overline{\mathrm{R}}^{2}=0.827 \quad \mathrm{SE}=1.182 \quad \mathrm{DW}=1.83
\end{aligned}
$$

Adding the extra observations produces some minor changes in the estimated coefficients. Even so, the basic ontcome reported in equation 1 is duplicated in equation 1 '.
}

rate of inflation for 1983 is over 6.5 percent, and rates for 1984 and 1985 exceed 7 percent.

What if the downward drift in relative energy prices continues throughout $1983 ?^{18}$ To see what effect these further reductions in relative energy prices would have on inflation through 1985, simulations were produced assuming that relative energy prices will decline throughout 1983, but remain constant from 1984 onward. ${ }^{19}$ These simulations are reported in the second column of table 2.

The simulations using both money and relative energy prices are lower than the "money only" results for 1983 and 1984; by 1985, however, the effects on the inflation rate of the lower relative energy prices in 1982 and 1983 have fully dissipated. At that time, the rate of inflation is simulated to return back to the average rate of money growth.

\section{CONCWUSTON}

Evidence presented in this article indicates that recent declines in inflation are due both to a drop in the average rate of money growth and to reductions in the relative price of energy. Once the favorable effects of these relative energy price declines abate and assuming no changes in the historical money growth-inflation link, inflation will tend to move back in line with the average growth of money. Thus, even if relative energy prices decline over the rest of 1983 , unless the average rate of $M 1$ growth declines, it is premature to conclude that "runaway inflation is now safely behind us."20

${ }^{18}$ For an analysis suggesting that this may occar, see Mack Ott and
John A. Tatom, "Are There Adverse Inflation Effects Associated
with Natural Gas Decontrol?" Contemporary Polict Isstues (Octo"
ber 1981 ), pp. $27-46$.
19 The assumptions used are that the relative price of energy will
decline during 1983 at rates of 22.4 percent, 20.0 percent and 6.0
percent in each of the final two quarters. I would like to thank Jack
Tatom for these figures.
${ }^{20}$ This statement is from Martin Feldstein, quoted in Stern, "Economists Optimistic on Inflation Outlook." 